\author{
M. Bukenov, A. Ibrayev, D. Zhussupova, D. Azimova \\ L.N. Gumilyov Eurasian National University, Astana, Kazakhstan \\ (E-mail: zhus.dinara@yandex.kz)
}

\title{
Numerical solution of a problem on bending oscillation of a rod
}

\begin{abstract}
In article considered the problem of curved rod fluctuation with JungB ${ }^{\mathrm{TM}^{\mathrm{T}}}$ s module. Shown the civility of the problem formulation. For solution used integro - interpolation method. Constructed implicit differential scheme, which realized by five - point sweep method. Conducted numerical calculations showed coincidence of theoretical calculation values of solution. Calculations conducted on the system of computer algebra Wolfram Mathematica. Results of calculations are given for two cases of fixing ends of the rod: both ends are fixed and one end is fixed other is free.
\end{abstract}

Keywords: difference scheme, pentadiagonal sweep method, oscillations of a rod, YoungB ${ }^{\mathrm{TM}}{ }_{\mathrm{s}}$ module, integro-interpolation method.

Let us consider a rod with length $l$ with rectilinear axis of variable, but not swirling cross-section, executing bending oscillations in plane $O x y z$ ( $O x$ axis is directed along rod axis and passes through centers of gravity of cross-sections; $O y$ and $O z$ are main axes, so $\left.\int_{F} y z d F=\int_{F} y d F=\int_{F} z d F=0\right)$. Let us suppose that cross at deformation stay flat and perpendicular to deformed axes of the rod, while normal stresses on areas parallel to the axle are small to negligible. Essential of tensor components of stress and deformation are $\sigma_{11}$ and $\varepsilon_{11}$. Axle elongation is neglected. Potential energy of deformation and kinetic energy relate to rod bend as follows:

$$
U=\frac{1}{2} \int_{0}^{l} E J\left(\frac{\partial^{2} w}{\partial x^{2}}\right)^{2} d x, T=\frac{1}{2} \int_{0}^{l} \rho F\left(\frac{\partial w}{\partial t}\right)^{2} d x
$$

where $J=\int_{F} z^{2} d F$ - is a moment of inertial of cross section relative to $O y$. Bending rod oscillations are described by equations $[1,2]$ :

$$
\rho \frac{\partial^{2} w}{\partial t^{2}}+S \frac{\partial^{2}}{\partial x^{2}}\left(E(x) \frac{\partial^{2} w}{\partial x^{2}}\right)=q(x, t)
$$

initial conditions

$$
\left.w\right|_{t=0}=u_{0}(x) ;\left.\frac{\partial w}{\partial \mathrm{t}}\right|_{t=0}=u_{1}(x)
$$

boundary conditions:

$$
\begin{gathered}
\left.w\right|_{x=0}=0 ;\left.\frac{\partial w}{\partial x}\right|_{x=0}=0 \\
\left.\frac{\partial}{\partial x}\left(E \frac{\partial^{2} w}{\partial x^{2}}\right)\right|_{x=l}=0 ;\left.E \frac{\partial^{2} w}{\partial x^{2}}\right|_{x=l}=0
\end{gathered}
$$

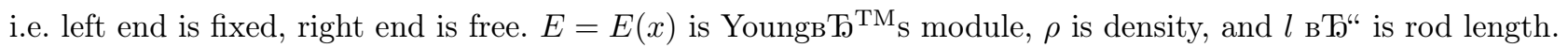

Let $D=[0, l], D_{T}=D \times[0, T], 0 \leq t \leq T$. Generalized solution of problem (1)-(4) let we name function $w \in W_{2}^{2,2}\left(D_{T}\right)$, for which an integral identity is made:

$$
\begin{gathered}
-\rho \int_{0}^{T}\left(\frac{\partial w}{\partial t}, \frac{\partial \Phi}{\partial t}\right)_{D} d t+\rho\left(u_{1}(x) ; \Phi_{t}(x, 0)\right)_{D}+\rho\left(u_{0}(x), \Phi(x, 0)\right)_{D}+ \\
+-\rho \int_{0}^{T}\left(\frac{\partial w}{\partial t}, \frac{\partial \Phi}{\partial t}\right)_{D} d t+\rho\left(u_{1}(x) ; \Phi_{t}(x, 0)\right)_{D}+\rho\left(u_{0}(x), \Phi(x, 0)\right)_{D}+
\end{gathered}
$$




$$
+\int_{0}^{T}\left(a \frac{\partial^{2} w}{\partial x^{2}}, \frac{\partial^{2} \Phi}{\partial x^{2}}\right)_{D} d t=\int_{0}^{T}(q, \Phi)_{D} d t
$$

$(u, v)_{D}=\int_{D} u(x, t) v(x, t) d x, a(x)=E(x)$, with any function $\Phi(x, t) \in W_{2}^{2,2}\left(D_{T}\right)$. It is easy to see that if $q(x, t) \in L_{2}\left(0, T ; L_{2}(D)\right), u_{0}(x) \in \stackrel{\circ}{W_{2}^{1}}, u_{1}(x) \in L_{2}(D)$, then problem (1)-(4) has only generalized solution, following [3]. To solve (1)-(4) using integro - interpolation method [4] construct implicit conservative scheme:

$$
\begin{gathered}
\omega_{\tau}=\left\{t_{n}=n \tau, n=0,1,2 \ldots, M, M=[T / \tau]\right\} \\
\omega_{h}=\left\{x_{i}=i h, i=0,1,2 \ldots, N, h=l / N\right\} ; \\
\rho_{i} \frac{u_{i}^{n+1}-2 u_{i}^{n}+u_{i}^{n-1}}{\tau^{2}}+S\left(a_{i+2} \frac{u_{i+2}^{n+1}-u_{i+1}^{n+1}}{h^{4}}-3 a_{i+1} \frac{u_{i+1}^{n+1}-u_{i}^{n+1}}{h^{4}}+3 a_{i} \frac{u_{i}^{n+1}-u_{i-1}^{n+1}}{h^{4}}-\right. \\
\left.-a_{i-1} \frac{u_{i-1}^{n+1}-u_{i-2}^{n+1}}{h^{4}}\right)=q_{i}^{n}, i=2, \ldots, N-2, \quad n=1, \ldots, M-1 .
\end{gathered}
$$

Let us add approximation of initial and boundary conditions

$$
\begin{gathered}
u_{i}^{0}=0, u_{i}^{1}=u_{i}^{0}+\frac{\tau\left(\Lambda u_{i}^{0}-q_{i}^{0}\right)}{2} ; \\
u_{0}^{n}=0,-u_{2}^{n}-4 u_{1}^{n}+5 u_{0}^{n}=0, u_{N}^{n}-2 u_{N-1}^{n}+u_{N-2}^{n}=0 ; \\
a_{N-1} u_{N}^{n}-\left(a_{N-2}+2 a_{N-1}\right) u_{N-1}^{n}+\left(a_{N-1}+2 a_{N-2}\right) u_{N-2}^{n}-a_{N-2} u_{N-3}^{n}=0 ; \\
a_{i}=a\left(x_{i}-0.5 h\right) ; \\
\Lambda u^{n}=S\left(a_{i+2} \frac{u_{i+2}^{n}-u_{i+1}^{n}}{h^{4}}-3 a_{i+1} \frac{u_{i+1}^{n}-u_{i}^{n}}{h^{4}}+3 a_{i} \frac{u_{i}^{n}-u_{i-1}^{n}}{h^{4}}-a_{i-1} \frac{u_{i-1}^{n}-u_{i-2}^{n}}{h^{4}}\right) .
\end{gathered}
$$

Scheme (6)-(8) has an error $O\left(\tau^{2}+h^{2}\right)$. Following (4), let us bring scheme (6) to canonical form

$$
B u_{\grave{t}}+\tau^{2} R u_{\bar{t} t}+\Lambda u=\varphi,
$$

where $B=0, R=E / \tau^{2}$, then from (9), following [4] we establish that scheme (6)-(8) is stable on the right part and initial data; using different analogs of embedding theorems [5], it is easy to see that if $z=U-W$ error between $U$ - difference solution of problem (6)-(8) and solution W - of differential problem (1)-(4) then there is a convergence, namely

$$
\|z\|_{W_{2 . h}^{2.2}\left(D_{h}\right)} \leqslant C\left(\tau^{2}+h^{2}\right) .
$$

To solve difference scheme (6)-(8) pentadiagonal sweep method [6]. To this end in (6) let us transfer elements on layer $n+1$ to the first part, then we get the following system

$$
a_{i} y_{i-2}-b_{i} y_{i-1}+c_{i} y_{i}-d_{i} y_{i+1}+e_{i} y_{i+2}=f_{i}, \quad i=2, \ldots, N-2 .
$$

We will solve it using pentadiagonal sweep method algorithm. Here we attach graphs of bend behavior on different time steps, which demonstrate quality conformity with practical results.

The values of steps in the construction of the graphs given above are as follows

$$
\tau=h=0.001 \text {. }
$$


In Figure 1 is a graph of the flexural oscillations of the rod, one end of which is fixed, and the second is free for various time steps. Constant coefficients and functions in equation (1) were taken as follows

$$
\rho=1.0, J=1.0 ; F=1.0, a(x)=1.0 ; q(x, t)=\delta\left(x-v_{0} t\right) ; v_{0}=20.0,
$$

where $\delta$-delta-function; $v_{0}-$ speed of acting force $F$.

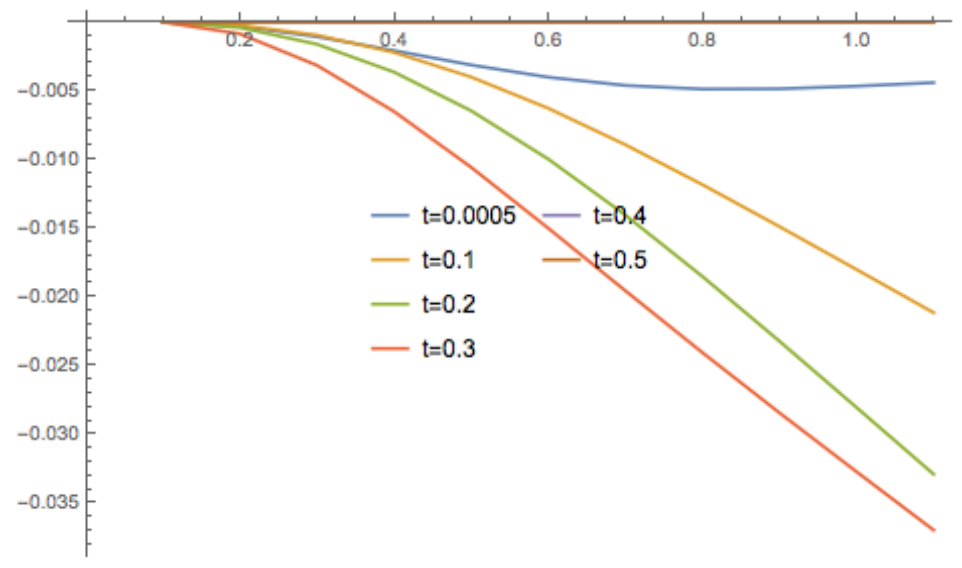

Figure 1. Graph of flexural oscillations of the rod, one end of which is fixed and the second is free

In Figure 2 is a graph of the flexural oscillations of the rod, both ends of which are fixed, for different time steps. Constant coefficients and functions in equation (1) were taken as follows:

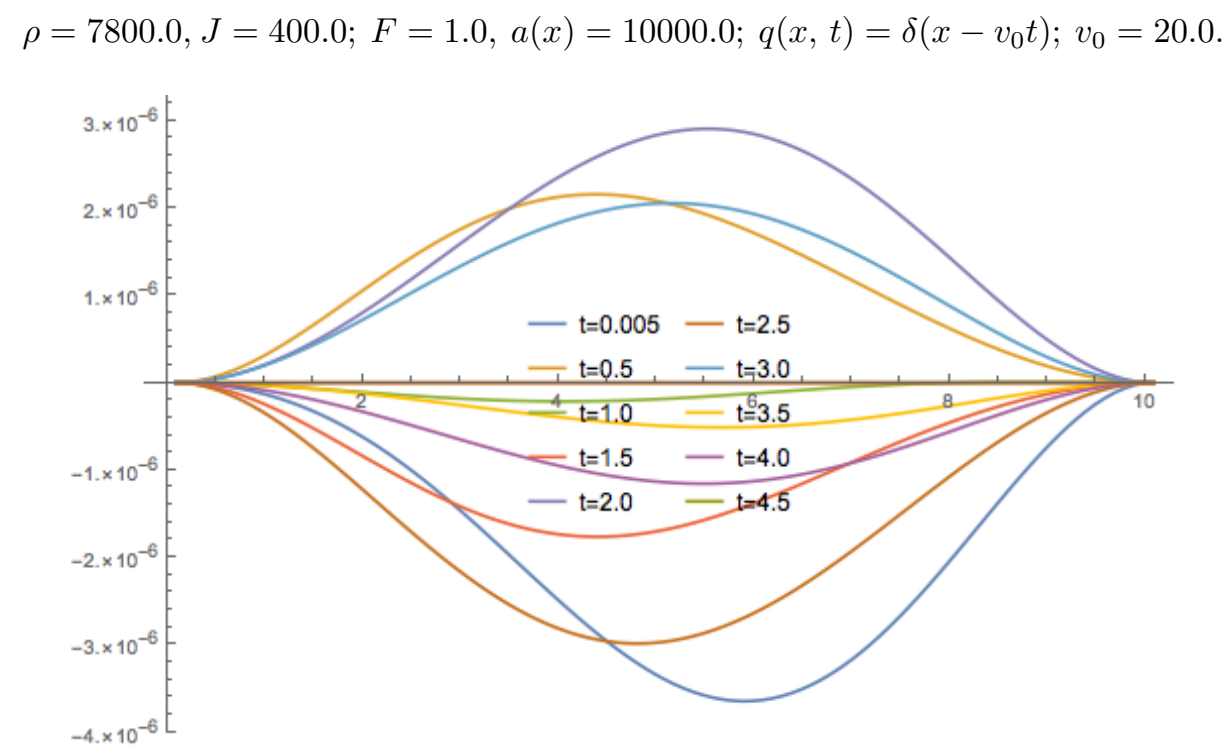

Figure 2. The graph of the flexural oscillations of the rod, both ends of which are fixed

Checked comparison with the test solution. The results showed qualitative coincidence of the numerical solution with the test solution on different grids. Conclusion: the proposed algorithm showed its practical effectiveness for the numerical solution of the original problem. 


\title{
References
}

1 Бидерман В.Л. Теория механических колебаний / В.Л. Бидерман. - М.: Наука, 1980. - 408 с.

2 Пановко Я.Г. Устойчивость и колебания упругих систем / Я.Г. Пановко, И.И. Губанова. - М.: Наука, 1987. - 352 с.

3 Ладыженская О.А. Краевые задачи математической физики / О.А. Ладыженская. - М.: Наука, 1973. - 407 с.

4 Самарский А.А. Теория разностных схем / А.А. Самарский. - М.: Наука, 1977. - 657 с.

5 Андреев В.Б. Разностные методы для эллиптических уравнений / В.Б. Андреев, А.А. Самарский. - M.: Наука, 1976. - 354 с.

6 Николаев Е.С. Методы решения сеточных уравнений / Е.С. Николаев, А.А. Самарский. - М.: Наука, 1978. - 592 c.

\section{М. Букенов, А. Ибраев, Д. Жусупова, Д. Азимова}

\section{Сымның иілмелі тербеліс есебінің сандық шешімі}

\begin{abstract}
Мақалада Юнг модулі айнымалы болатын сымның иілмелі тербелістері туралы есеп қарастырылды. Есептің қисындылығы дәлелденді. Есепті шешуде интегралдық-интерполяциялық әдіс қолданылған. Айқындалмаған айырымдық схема құрастырылып, беснүктелі қуалау әдісімен шешілген. Жүргізілген есептеулер нәтижелердің теориялық мәндерімен беттесетіні көрсетілді. Барлық есептеулер Wolfram Mathematica компьютерлік алгебра жүйесінде жіргізілді. Есептеулердің нәтижелері сымның екі ұшына екі түрлі әдіспен бекітілген (екі ұшы қатаң бекітілген және бір ұшы қатаң бекітілген, ал екіншісі - бос) жағдайы үшін келтірілген.
\end{abstract}

Kiлm сөздер: айырымды схема, беснүктелі қуалау әдісі, сымның тербелістері, Юнг модулі, интегралдық-интерполяциялық әдіс.

\author{
М. Букенов, А. Ибраев, Д. Жусупова, Д. Азимова
}

\section{Численное решение задачи об изгибном колебании стержня}

В статье рассмотрена задача изгибных колебаний стержня с переменным модулем Юнга. Показана корректность постановки задачи. Для решения задачи использовался интегро-интерполяционный метод. Построена неявная разностная схема, которая реализована методом пятиточечной прогонки. Проведенные численные расчеты показали качественное совпадение теоретических расчетных значений решения. Вычисления выполнялись в системе компьютерной алгебры Wolfram Mathematica. Результаты вычислений приведены для двух случаев закрепления концов стержня: два конца закреплены жестко и один конец - заделка, а второй - свободный.

Ключевые слова: разностная схема, метод пятиточечной прогонки, колебания стержня, модуль Юнга, интегро-интерполяционный метод.

\section{References}

1 Biderman, V.L. (1980). Teoriia mekhanicheskikh kolebanii [Theory of mechanical oscillations]. Moscow: Nauka [in Russian[.

2 Panovko, Ya.G., Gubanova, I.I. (1987). Ustoichivost $i$ kolebaniia upruhikh sistem [Stability and fluctuations of elastic systems]. Moscow: Nauka [in Russian].

3 Ladizhenskaya, O.A. (1973). Kraevye zadachi matematicheskoi fiziki [Boundary problems of mathematical physics]. Moscow: Nauka [in Russian]. 
4 Samarskii, A.A. (1977). Teoriia raznostnykh skhem [Theory of differential schemes]. Moscow: Nauka [in Russian].

5 Andreev, V.B., Samarskii, A.A. (1976). Raznostnye metody dlia ellipticheskikh uravnenii [Differential methods for the elliptic equations]. Moscow: Nauka [in Russian].

6 Nikolaev, E.S., Samarskii, A.A. (1978). Metody resheniia setochnykh uravnenii [Methods of the solution of the net equations]. Moscow: Nauka [in Russian]. 